\title{
Level Of Schooling And Gender Differences In Test Anxiety Among Secondary School Students In Port Harcourt Local Government Area Of Rivers State
}

\author{
Jonathan N. Onukwufor Ph.D \\ Department of Educational Psychology Guidance And Counselling \\ University of Port Harcourt \\ Port Harcourt, Rivers State Nigeria \\ Chinelo J. Ugwu Ph.D \\ Department of Educational Psychology Guidance and Counselling \\ University of Port Harcourt \\ Port harcourt, Rivers state Nigeria
}

\begin{abstract}
This research was conducted to ascertain the level of schooling and gender differences in secondary school students' test anxiety. The study was carried out in Port Harcourt Local Government Area of Rivers State. The population of the study was made up of all the Junior Secondary School class two (JSS 2) students and all senior secondary school class two (SSS 2) students in Port Harcourt Local Government Area of Rivers State. Simple random sampling and stratified random sampling techniques were used to draw a sample of 308 students which comprised 108 JSS and 200 SSS 2 students. The sample was also made up of 136 females and 172 male students. The instrument used for the study was captioned Test Anxiety Inventory (TAI). The instrument was validated and Crombach Alpha was used to determine the reliability of the instrument and the reliability coefficient obtained was 0.75 . Two research questions and two hypotheses guided the study. The findings of the study are as follows: There was significant difference between JSS and SSS students test anxiety. Senior secondary school students significantly had more test anxiety than Junior Secondary School students. There was significant difference between male and female students' test anxiety in Port Harcourt Local Government Area of Rivers State. The female students significantly had more test anxiety than male students, some recommendations were made, which includes that teachers should prepare students adequately for any examination they are to write especially external examinations so as to instill great confidence in the students.
\end{abstract}

Keyword: Test anxiety, level of schooling, gender and three factor model of test anxiety

\section{INTRODUCTION}

Test anxiety is a component of emotional arousal which is common among all human beings. Test anxiety is the tendency for a person to be frightened before or when writing a test or an examination. According to Colman (2003:736) test anxiety is a "state anxiety aroused by the event or prospect of taking a test or examination" implicit in the above definition is that test anxiety is uneasiness, worry and tension which some individuals experience when writing a test or an examination. According to Onukwufor and Ugwu (2017), the fear and worry which the examinee exhibits during test or examination is known as test anxiety. Ormrod (2008: 585) defined test anxiety as "excessive anxiety about a particular test or about assessment in general" this definition implies that test anxiety is too much nervous feeling caused by feeling of possible unpleasant outcome during an assessment. The fear of unpleasant outcome may be 
anticipated poor academic performance which causes tremendous worry to the testee. Aydin (2017) defined test anxiety as a negative emotional response to current or prospective situation involving an evaluation. Some students tend to exhibit anxious behaviour during tests and other essential assessment. It has been stated that a little amount of anxiety can enhance performance (Ormrod 2008). Test anxiety occurs when students are very anxious in assessment situations which culminates in students' academic under achievement. Examinees who exhibit test anxiety are usually afraid of poor performance during such an assessment. Such testees may be more worried during a test or examination which they find difficult; if they remember the extent of negative reaction and castigation which their poor performance will attract from parents, teachers and even class mates who will look upon them with contempt and see them as dullards. Some test anxiety students refrain from attending school or pretend to be sick during examination. According to Bernstein, Penner, Clarke - Stewart and Roy (2006) people who experience test anxiety in an examination or test tend to obtain low grade and physically exhibit symptoms such as heart palpitation and sweating, headache, nausea, diarrhea, shortness of breath, rapid heart beat, light headedness and feeling faint; while emotional symptoms include feeling of anger, fear, helplessness and disappointment in addition to negative cognitive feelings (Bernstein et al 2006; https//adaa.org).

The highlighted symptoms lead us to the three factor model of test anxiety as postulated by Wren and Benson (2004) which comprise cognitive, behavioural and physiological components. The cognitive dimension include perturbing and irrelevant test thoughts such as: causing sorrow to parents due to poor performance or unfavourable comparison of the testees performance with that of his peers or class mates. The behavioral component which is also known as off task behaviours essentially focuses on nervous habits which includes: automanipulation such as playing with hair or biting pencil or pen during assessment. According to Dydin (2017), the physiological dimension which is also known as autonomic reaction displays physiological arousal and somatic signs of anxiety. Physiological component of test anxiety manifest in perspiring, dizziness and increased galvanic skin response.

Level of schooling which is an independent variable in this study refers to Junior Secondary school (JSS) and Senior Secondary Schools (SSS) collectively. To the best knowledge of the researchers, sufficient researches have not been conducted in the area of level of schooling test anxiety differences. In a study conducted by Akanbi (n.d) no statistical significant difference was found in test anxiety scores of the participants based on year of study. In another study conducted in Turkey, Aydin (2017) found that overall test anxiety declined from primary to middle school. Studies conducted by Oksal, Durmaz and Akin (2013); Yenilmez and Ozabaci as cited in Aydin (2017) showed that no significant differences exist in test anxiety among middle and high school students. Onukwufor and Ugwu(2017) found that test anxiety significantly negatively predicted students academic achievement in physics.

Majority of the studies conducted by researchers on gender differences in secondary school students test anxiety have found that female students tend to suffer from test anxiety than male students Akanbi (n.d) found significant test anxiety difference across gender. Aydin (2017) in a study he conducted in Turkey reported that overall test anxiety declined with females showing higher test anxiety throughout school years. Other researchers such as Lowe and Lee (2008), Hembree (1988), Putwain (2007), Segool, Carison, Goborth, Von Der Embse, and Barterian (2013), including Putwain and Daly (2014) consistently found that female students reported higher levels of test anxiety than male students. However, a study conducted by Sandhu (2016) found no significant difference in the anxiety of male and female students. 


\section{HOW TO REDUCE TEST ANXIETY}

According to Sawchuk (2017), test anxiety could be reduced as follows:

1. Learn how to study efficiently

2. Study early and in similar places

3. Establish a consistent pretest routine

4. Talk to your teacher

5. Learn relaxation technique

6. Don't forget to eat and drink

7. Get some exercise

8. Get plenty of sleep

\section{STATEMENT OF PROBLEM}

Test anxiety is a general problem experienced by many students both at the primary, secondary and tertiary levels of learning. Text anxiety may occur due to inadequate preparation for the assessment. Inadequate preparation may stem from lack of study skills, absenteeism inattentiveness in the classroom, lack of text books, refusal to write notes in the class and lack of interest in reading especially to prepare for tests and examinations. When a student hesitates to prepare adequately for an assessment, he may find most questions difficult. A situation of this nature frightens the student, which causes the examinee to exhibit some physical symptoms such as sudden sweating while writing and headache. These symptoms are detrimental to high academic achievement. Hence, the academic performance of students who experience high test anxiety is bound to be low. Students who perform poorly in their academic pursuit may either fail out or withdraw, thereby becoming a school dropout. Thus test anxiety is detrimental to student's academic achievement. The problem of this study therefore is to ascertain the level of schooling and gender differences in test anxiety among secondary school students in Port Harcourt Local Government Area of Rivers State.

\section{Research Questions}

This study was guided by the following research questions:

1. What is the difference between JSS and SSS students test anxiety in Port Harcourt LGA of Rivers State.

2. What is the difference between male and female students test anxiety in Port Harcourt LGA of Rivers State.

\section{Hypotheses}

The following null hypotheses were tested at 0.05 alpha level:

1. There is no significant difference between JSS and SSS students test anxiety in Port Harcourt Local Government Area of Rivers State.

2. There is no significant difference between male and female students test anxiety in Port Harcourt Local Government Area of Rivers State.

\section{METHODOLOGY}

The research design adopted for this study is descriptive survey. The population for the study was made up of all the JSS 2 and SSS 2 students in Port Harcourt Local Government Area of Rivers State. The sample for the study was made up of 308 students which comprised 108 JSS students and 200 SSS 2 students. The sample was also made up of 136 females and 172 male students. The sample was drawn from 4 secondary schools in Port Harcourt Local Government Area, using simple random sampling and stratified random sampling techniques. The instrument used for the study was captioned Test Anxiety Inventory (TAI) which was developed by the researchers. The instrument contained eleven items which measured test anxiety. The questionnaire was validated by three experts in the Department of Educational 
Psychology Guidance and Counseling, University of Port Harcourt. Cronbach Alpha was used to determine the reliability of the instrument. The reliability co-efficient obtained was 0.75 , the co-efficient was considered high enough to warrant the use of the instrument for the study. The four likert rating scale of strongly agree (SA), Agree (A), Disagree (D) and strongly disagree (SD) were used to measure the respondents response as follows: $S A=4, A=3, D=2$, and $S D=1$. The minimum score obtained by a respondent was 11 points, while the maximum score obtainable by any respondent was 44 . Mean standard deviation and t-test were the statistical techniques used to answer the research questions and to test the hypotheses.

\section{RESULTS}

The results of the research questions and hypotheses of the study are presented in the tables below.

\section{Research Question One}

What is the difference between JSS and SSS students test anxiety in Port Harcourt Local Government Area of Rivers State?

\section{Hypothesis One}

There is no significant difference between JSS and SSS students test anxiety in Port Harcourt Local Government Area of Rivers State?

Table 1: T-test analysis of JSS and SSS students test anxiety

\begin{tabular}{lllllllll}
\hline School Level & $\mathbf{N}$ & $\bar{X}$ & SD & Df & T cal & & Sig & Decision \\
\hline JSS & 108 & 17.2963 & 4.93 & 306 & -4.7 & 0.05 & 000 & Significant \\
SSS & 200 & 20.4600 & 5.97 & & & & &
\end{tabular}

Table 1 shows that the computed JSS test anxiety mean score is 17.2969 and standard deviation of 4.93, while the SSS mean score is 20.4600 and standard deviation of 5.97. The SSS students test anxiety mean score is higher than the JSS test anxiety mean score. The mean difference between JSS and SSS students test anxiety mean score is -3.1637. The computed value of 000 is less than p critical value of $0.05(\mathrm{p}<0.05)$ at $306 \mathrm{df}$. The null hypothesis is therefore rejected. This means that there is a significant difference between JSS and SSS students test anxiety.

\section{Research Question Two}

What is the difference between male and female students test anxiety in Port Harcourt Local Government Area of Rivers State?

\section{Hypothesis Two:}

There is no significant difference between male and female secondary school students test anxiety.

Table 2: T-test analysis of male and female secondary school students test anxiety in Port Harcourt Local Government Area of Rivers State?

\begin{tabular}{lcccccccc}
\hline Gender & $\mathbf{N}$ & $\overline{\mathbf{X}}$ & SD & Df & T cal & & Sig & Decision \\
\hline Male & 172 & 18.2791 & 6.3956 & 306 & -4758 & 0.05 & 000 & Significant \\
Female & 136 & 21.9706 & 7.1987 & & & & &
\end{tabular}

Table 2 shows that the computed male test anxiety mean is 18.2791 and standard deviation of 6.3956 female test anxiety mean is 21.9706 and a standard deviation of 7.1987. The female students test anxiety mean is higher than that of male students. The mean difference between 
male and female students test anxiety is -3.6915 , the computed value of 000 is less than $\mathrm{p}$ critical value of $0.05(\mathrm{p}<0.05)$ at $306 \mathrm{df}$. The null hypothesis is therefore rejected. This means that there is a significant difference between male and female students test anxiety.

\section{SUMMARY OF FINDINGS}

1. There was significant difference between JSS and SSS students test anxiety and senior secondary school students significantly had more test anxiety than junior secondary school students.

2. There was significant difference between male and female students test anxiety. Female secondary school students significantly had more test anxiety than male students in Port Harcourt Local Government Area of Rivers State.

\section{JSS and SSS Students Test Anxiety}

\section{DISCUSSION}

Table one above showed that there was significant difference between JSS and SSS students test anxiety. Based on the finding that SSS students test anxiety mean $(\bar{x}=20.4600)$ was higher than JSS mean $(\bar{x}=17.2963)$ and the null hypothesis was rejected, it then means that the senior secondary school students significantly had more test anxiety than the junior secondary school students. The finding of this study in this regard is surprising and at variance with some previous studies. In a study conducted by Akanbi (n.d) no statistical significant difference was found in test anxiety scores of the respondents based on year of study. Aydin (2017) found that overall test anxiety declined from primary to middle school. Geographical differences could partly explain the difference in the findings. For instance the study of Aydin was conducted in Turkey while this was conducted in Nigeria. In Nigeria the senior secondary students are about to enter the university and they are aware of the difficulty in securing the admission through Joint Admission and Matriculation Board (JAMB) and other complex examinations ahead such as Senior Secondary Certificate Examination (SSCE) and Post University Matriculation Examination. The thought of all these examinations may frighten some of the SSS students, hence their significant test anxiety. The junior secondary school students may have only one major examination at stake which they may not attach much importance to because they may not adequately comprehend the relevance of such examination to their future hence their low level of test anxiety.

\section{Male and Female Students Test Anxiety}

Table 2 showed that there was significant difference between male and female students test anxiety. The female students test anxiety mean score $(\bar{x}=21.9706)$ was higher than the male students test anxiety mean $(\bar{x}=18.2791)$ score. The null hypothesis was rejected based on $\mathrm{t}$ test analysis result. Consequently it was found that female secondary school students significantly had more test anxiety than male secondary school students. This result was actually expected. The finding in this regard, is in consonance with the result of previous researches in similar topic. Thus the findings of this study supported Aydin (2017) that females showed higher test anxiety than males. Also, the finding is in consonance with Putwain and Daly (2013), Lower and Lee (2008), and Putwain (2017). The reason for this consistent result is because females are more emotional than males. However, Gandhu (2016) found no significant difference in male and female students test anxiety.

\section{RECOMMENDATION}

1. Government is required to post two guidance counselors each to both junior and senior secondary schools. 
2. Guidance counselors should counsel the SSS students on how to reduce their test anxiety.

3. Teachers should prepare students adequately for any examination they are to write, especially external examination, so as to instill great confidence in them.

4. Counsellors should through counseling assist the female students minimize their high level of emotionality and also counsel them on how to reduce their test anxiety.

\section{CONCLUSION}

Based on the findings of this study, it was concluded that test anxiety amongs secondary school students vary based on level of schooling and based on gender. Thus, senior secondary school students significantly had more test anxiety than junior secondary school students. Also female secondary school students significantly had more test anxiety than the male secondary school students in Port Harcourt Local Government Area of Rivers State Nigeria.

\section{References}

Akanbi, S.T. (n.d). Comparisons of test anxiety level of senior secondary school students across gender, year of study, school type and parental educational background. Retrieved January $6^{\text {th }}, 2018$. from:https//www.questia.com/library/journal/1p-3-2951704451/comparison...

Aydin, U. (2017). Test anxiety: Do gender and school-level matter? European Journal of Educational Research, 6(2), 187-197.

Bernstein, D.A, Penner, L.A., Clarke - Stewart, A., Roy, E.J. (2006). Psychology (7th ed). Boston: Houghton mifjin. Colman, A.M. (2003). A Dictionary of psyczhology. New York: Oxford University Press.

Hembree, R. (1988). Correlates, causes, and treatment of test anxiety. Review of Educational Research, 58(1) 4777.

Lowe, P.A. \& Lee, S.W. (2008). Factor structure of the test anxiety inventory for children and adolescents (TALCA): Scores across gender among students in primary and secondary school settings. Journal of psychoeducational assessment, 26(3), 231-246.

Ormrod, J.E. (2008). Educational psychology: Developing learners (6 $6^{\text {th }}$ ed) New Jersey: Reason Prentice Hall. Onukwufor, J.N. \& Ugwu, C. J. (2017). Self- concept, test anxiety and achievement motivation as predictors of academic achievement in physics among secondary school students in Rivers State Nigeria. Journal of Education and Practice, 8,(33),99-106.

Putusain, D., \& Daly, A.L. (2014). Test anxiety, prevalence and gender differences in a sample of English secondary school students. Educational Studies, 40(5), 554-570.

Putwain, D.W. (2007). Test anxiety in UK school children: Prevalence and demographic patterns. British Journal of Educational Psychology, 77(3), 579-593.

Sandhu, S.S. (2016). Anxiety among senior secondary school students in relation to gender. Retrieved January $6^{\text {th }}$ 2018. from: ierj.in/journal/index.php/ierj/article/view/4191396.

Sawchuk, C.N. (2017). How to reduce test anxiety. Retrieved January $29^{\text {th }} 2018$, from:https://www.google.com/search.

Segool, N.K., Carlson, J.S., Goforth, A.N; Von Der Embse, N., \& Barterian, J.A. (2013). Heightened test anxiety among young children: Primary school students anxious responses to high-stakes testing. Psychology in the schools, 50(5), 489-499.

Wren, D.G \& Benson, J.C. (2004). Measuring test anxiety in children: Scale development and internal construct validation. Anxiety, Stress \& Coping, 17(3), 227-240. 